\title{
Commentary \\ Dextran-70 to modulate inflammatory response after cardiopulmonary bypass: potential for a novel approach?
}

Tobias Schuerholz and Gernot Marx

${ }^{1}$ Department of Anesthesiology and Intensive Care, Friedrich-Schiller-University, Erlanger Allee 101, 07747 Jena, Germany

Corresponding author: Gernot Marx, gernot.marx@med.uni-jena.de

Published: 5 September 2007

Critical Care 2007, 11:163 (doi:10.1186/cc6103)

This article is online at http://ccforum.com/content/11/5/163

(C) 2007 BioMed Central Ltd

See related research by Gombocz et al., http://ccforum.com/content/11/4/R87

\begin{abstract}
Potential deleterious effects of cardiopulmonary bypass (CPB) and cardioplegic cardiac arrest are known to influence outcome. The inflammatory response after CPB may have unfavourable effects especially in high-risk patients, for example, the very elderly. Thus, to blunt the release of pro-inflammatory mediators seems to be a promising approach. So far, numerous attempts at immune modulation have been performed. However, the management of cardiac surgery patients needs further improvement. In this context, Gombocz and colleagues investigated the potential antiinflammatory effect of dextran-70. Their results suggest that compared to gelatine, dextran-70 reduces the inflammatory response in patients after $\mathrm{CPB}$.
\end{abstract}

Gombocz and colleagues performed a prospective, randomized, double blind study in 40 patients undergoing cardiopulmonary bypass (CPB). They investigated the anti-inflammatory potential of dextran-70 to modulate systemic inflammatory response syndrome (SIRS) and myocardial ischemia/reperfusion (I/R) injury following cardiac operations. Interestingly, they could demonstrate that the infusion of dextran-70 before and after CPB reduces inflammation and cardiac troponin I release [1].

The potential deleterious effects of coronary artery bypass grafting $(\mathrm{CABG})$ are well investigated under various conditions including CPB and off-pump coronary artery bypass (OPCAB). There are several underlying mechanisms behind the unfavourable effects of CPB. This includes the systemic inflammation response induced by contact between immune competent cells and the extracorporal circuit, the ischemiareperfusion injury of several organs, and the potential endotoxemia after splanchnic hypoperfusion and consecutive damage of the mucosal barrier [2]. It is well known that in low-risk patients the inflammatory response after CPB is less pronounced [3]. Avoiding CPB might improve the outcome even in elderly patients with higher morbidity [4] and might lead to good long-term results [5].

Nevertheless, the use of CPB is an essential requirement in certain cardiac surgery patients and routinely performed in cardiac surgery. The inflammatory response to CPB is accompanied by an increase in body temperature, leucocytosis and tissue oedema [2] as well as an increased release of cytokines such as interleukin-6 (IL-6) and IL-10 [6]. This was the rationale for investigations of immune modulation by corticosteroids [7], cyclooxygenase inhibitors [8], complement directed therapies [9], and adhesion molecule blockade [10]. The need for further studies was demonstrated by new insights regarding the therapy with aprotinin. Recently, it was shown that this widely used drug in cardiac surgery is associated with an increased risk of death even in long-term follow up after five years [11].

Gene array analysis revealed that leukocytes overexpress adhesion and signalling proteins after CPB which may lead to succeeding tissue inflammation [12]. Modulation of the inflammatory response seems to be an interesting therapeutic approach.

Previously, an anti-inflammatory effect of dextran could be demonstrated in experimental settings. Steinbauer and colleagues showed in ischemia-reperfusion injury in striated muscle, using intravital microscopy, that dextran attenuates postischemic leukocyte rolling in a molecular weight dependent manner [13].

In this context, the study by Gombocz and colleagues [1] yields interesting aspects on the immune modulation by

$\mathrm{CABG}=$ coronary artery bypass grafting; $\mathrm{CPB}=$ cardiopulmonary bypass; $\mathrm{IL}=$ interleukin; $\mathrm{I} / \mathrm{R}=$ ischemia/reperfusion; OPCAB $=$ off pump coronary artery bypass; $\mathrm{SIRS}=$ systemic inflammatory response syndrome. 
dextran-70 in patients undergoing CABG. Using dextran-70 infusion in the early post-CPB phase is associated with lower inflammation when compared to gelatine. After 24 hours procalcitonin as well as cardiac troponin I and soluble adhesion molecules were found to be lower using dextran-70 [1]. Thus, this study suggests that compared to gelatine, dextran-70 reduces the inflammatory response in patients after CPB.

Some limitations of the study by Gombocz and colleagues need to be addressed: the single centre design including a small number of patients and a short observation period of approximately two days [1]. Nevertheless, the authors succeeded to further the exciting area of peri-operative inflammation in cardiac surgery.

As so often, further investigations are warranted to evaluate the effects of dextran-70 treatment in cardiac surgery. These trials need to be limited to high-risk patients most likely to experience benefit by anti-inflammatory therapies. Additionally, a combination of plasma inflammatory mediators and gene array analysis may lead to the identification of patients being more susceptible to harmful effects of CPB.

\section{Competing interests}

GM has done paid consultation and verbal presentations for B Braun Melsungen AG, Germany. GM has performed research projects in collaboration with $B$ Braun Melsungen $A G$ and has thereby received other funding in the past. GM has also received fees for presentations and funds for performing research projects from Serumwerke Bernburg, Germany. TS has no competing interests.

\section{References}

1. Gombocz K, Beledi A, Alotti N, Kecskes G, Gabor V, Bogar L, Koszegi T, Garai J: Influence of dextran-70 on systemic inflammatory response and myocardial ischaemia - reperfusion following cardiac operations. Crit Care 2007, 11:R87.

2. Laffey JG, Boylan JF, Cheng DC: The systemic inflammatory response to cardiac surgery: implications for the anesthesiologist. Anesthesiology 2002, 97:215-52.

3. Czerny M, Baumer H, Kilo J, Lassnigg A, Hamwi A, Vukovich T, Wolner E, Grimm M: Inflammatory response and myocardial injury following coronary artery bypass grafting with or without cardiopulmonary bypass. Eur J Cardiothorac Surg 2000, 17:737-42.

4. Al-Ruzzeh S, Nakamura K, Athanasiou T, Modine T, George S, Yacoub M, Ilsley C, Amrani M: Does off-pump coronary artery bypass (OPCAB) surgery improve the outcome in high-risk patients?: a comparative study of 1398 patients. Eur J Cardiothorac Surg 2003, 23:50-55.

5. El-Hamamsy I, Cartier R, Demers P, Bouchard D, Pellerin M: Long-term results after systemic off-pump coronary artery bypass graft surgery in 1000 consecutive patients. Circulation 2006, 114:1486-91.

6. Wan S, Marchant A, DeSmet JM, Antoine M, Zhang H, Vachiery JL, Goldman M, Vincent JL, LeClerc JL: Human cytokine responses to cardiac transplantation and coronary artery bypass grafting. J Thorac Cardiovasc Surg 1996, 111:469-77.

7. Kawamura T, Inada K, Nara N, Wakusawa R, Endo S: Influence of methylprednisolone on cytokine balance during cardiac surgery. Crit Care Med 1999, 27:545-8.

8. Shafique T, Johnson RG, Dai HB, Weintraub RM, Sellke FW: Altered pulmonary microvascular reactivity after total cardiopulmonary bypass. J Thorac Cardiovasc Surg 1993, 106:479-86.
9. Fitch JC, Rollins S, Matis L, Alford B, Aranki S, Collard CD, Dewar M, Elefteriades J, Hines R, Kopf G et al.: Pharmacology and biological efficacy of a recombinant, humanized, single-chain antibody C5 complement inhibitor in patients undergoing coronary artery bypass graft surgery with cardiopulmonary bypass. Circulation 1999, 100:2499-506.

10. Gillinov AM, Redmond JM, Zehr KJ, Wilson IC, Curtis WE, Bator JM, Burch RM, Reitz BA, Baumgartner WA, Herskowitz A et al:: Inhibition of neutrophil adhesion during cardiopulmonary bypass. Ann Thorac Surg 1994, 57:126-33.

11. Mangano DT, Miao $Y$, Vuylsteke A, Tudor IC, Juneja R, Filipescu D, Hoeft A, Fontes ML, Hillel Z, Ott E et al.: Mortality associated with aprotinin during 5 years following coronary artery bypass graft surgery. JAMA 2007, 297:471-9.

12. Tomic V, Russwurm S, Moller E, Claus RA, Blaess M, Brunkhorst F, Bruegel M, Bode K, Bloos F, Wippermann J et al.: Transcriptomic and proteomic patterns of systemic inflammation in onpump and off-pump coronary artery bypass grafting. Circulation 2005, 112:2912-20.

13. Steinbauer M, Harris AG, Messmer K: Effects of dextran on microvascular ischemia-reperfusion injury in striated muscle. Am J Physiol 1997, 272:H1710-6. 